DOI: 10.32089/WBH.phw.2019.2(268).0008

orcid.org/0000-0003-2844-5442

\title{
Recenzja książki Bartłomieja Szyprowskiego Sąd Kapturowy przy Komendzie Głównej Związku Walki Zbrojnej w Warszawie (sierpień 1940 r. - listopad 1941 r.). Podziemie w walce ze zdrajcami Rzeczypospolitej, Warszawa 2016, ss. 403
}

W 2016 r. na rynku księgarskim ukazała się monografia Bartłomieja Szyprowskiego pt. Sąd Kapturowy przy Komendzie Głównej Związku Walki Zbrojnej w Warszawie (sierpień 1940 r. - listopad 1941 r.). Podziemie $w$ walce ze zdrajcami Rzeczypospolitej, która jest pokłosiem obronionej dwa lata wcześniej przez Autora dysertacji. Z radością przyjąłem wydanie tej publikacji, gdyż literatury naukowej poświęconej sądownictwu wojskowemu okresu II wojny światowej (zwłaszcza z terenów Polski okupowanej) jest bardzo mało ${ }^{1}$. Ponadto nie kryłem satysfakcji, bo - jak we Wstępie napisał Szyprowski (s. 9) - „celem publikacji jest przedstawienie działalności Sądu Kapturowego przy Komendzie Głównej ZWZ w Warszawie wraz z próbą analizy prawnej wydanych przez ten sąd orzeczeń". Z racji prawniczego wykształcenia i aktualnej profesji Autora (od 2008 r. pracuje w Prokuraturze Okręgowej w Warszawie-Pradze) spodziewać się należy rzetelnego i fachowego opracowania tego tematu, tym bardziej iż na łamach czasopism ukazywały się już wcześniej jego artykuły związane z tą problematyką, które czytałem $\mathrm{z}$ dużym zainteresowaniem².

\footnotetext{
1 Do najważniejszych monografii należy zaliczyć: P. M. Lisiewicz, $W$ imieniu Polski Podziemnej. Z dziejów Wojskowego Sądownictwa Specjalnego Armii Krajowej, Warszawa 1988; L. Gondek, Polska karząca 1939-1945. Polski podziemny wymiar sprawiedliwości w okresie okupacji niemieckiej, Warszawa 1988; idem, W imieniu Rzeczypospolitej. Wymiar sprawiedliwości w Polsce w czasie II wojny światowej, Warszawa 2011. Tematykę tę porusza też w swoich publikacjach m.in. Leszek Kania - zob. L. Kania, Przestępstwa przeciwko obowiązkowi wojskowemu i dyscyplinie $w$ polskim prawie karnym i praktyce sądów wojskowych $w$ latach 1795-1945, Sulechów 2010, s. 203-306; idem, Służba sprawiedliwości w Wojsku Polskim 1795-1945. Organizacja - Prawo - Ludzie, Siedlce 2015, s. 406-443.

2 W latach 2009-2014 Szyprowski publikował kilkakrotnie w „Wojskowym Przeglądzie Prawniczym”. Zob. bibliografię w recenzowanej książce - s. 302-303.
} 
Recenzowana praca ograniczona jest czasowo - od sierpnia 1940 r. do listopada 1941 r. Wybór ten wydaje się trafny, choć - w moim odczuciu - początkową datę należałoby przesunąć do kwietnia 1940 r., kiedy to Komitet Ministrów dla spraw Kraju we Francji podjął decyzję o utworzeniu pod okupacją dwóch rodzajów sądów - przy Związku Walki Zbrojnej (ZWZ) (pion wojskowy) i Delegaturze Rządu na Kraj (pion cywilny) ${ }^{3}$. Fakt ten znany jest Szyprowskiemu (s. 11), jednakże przesunięcie to argumentuje zorganizowaniem de facto, a nie de iure Sądów Kapturowych (SK). Końcowa cezura nie budzi zastrzeżeń, Autor słusznie zauważa, że pojawienie się w listopadzie $1941 \mathrm{r}$. Wojskowych Sądów Specjalnych wygasiło stopniowo działalność SK, które funkcjonowały na innych „zasadach prowadzenia procesu karnego” (s. 12). Tym niemniej w książce odnaleźć możemy wątki wykraczające poza ten okres i to nawet o 2 lata (por. s. 50-51, 122). Myślę, że jest to bardziej zaleta niż wada opracowania, ponieważ wyjaśnienie pewnych kwestii (zwłaszcza przy opisywaniu konkretnego postępowania wobec podejrzanego) likwidowało pojawiające się w trakcie czytania wątpliwości i doprecyzowywało fakty.

Baza źródłowa monografii Szyprowskiego w dużej mierze oparta jest na dokumentach z: Archiwum Akt Nowych, Biblioteki Uniwersyteckiej Uniwersytetu Warszawskiego, Instytutu Pamięci Narodowej (wszystkie znajdują się w Warszawie), Instytutu Polskiego i Muzeum im. gen. Sikorskiego oraz Studium Polski Podziemnej (oba w Londynie), a także Zakładu Narodowego im. Ossolińskich we Wrocławiu. Autor skorzystał z wielu drukowanych aktów prawnych, prasy, memuarystyki oraz publikacji. Niewątpliwie Szyprowski dokonał na tej płaszczyźnie solidnej kwerendy, co zasługuje na duże uznanie.

Cała książka składa się z czterech rozdziałów (w sumie 227 stron) opatrzonych wstępem, podsumowaniem, załącznikami, wykazem skrótów, bibliografią, indeksem nazwisk i pseudonimów ${ }^{4}$. W pierwszej części (26 stron) czytelnik wprowadzony zostaje $\mathrm{w}$ „klimat historyczny”, bowiem zapoznaje się z sytuacją Polski sprzed wybuchu II wojny światowej (od marca 1939 r.), początkiem okupacji terenów II Rzeczypospolitej i utworzeniem struktur Państwa Podziemnego.

W rozdziale drugim (46 stron) omówiona została organizacja formalno-prawna SK. Przedstawiono analizę kodeksu SK od strony materialnej i procesowej, nawiązując niejednokrotnie do innych aktów prawnych (np. kodeksu karnego czy kodeksu karnego wojskowego - oba z 1932 r.). Zabieg ten wydaje się ze wszech miar uzasadniony, gdyż ukazuje ciągłość prawną struktur polskiego podziemia i legalność działań specjalnych sądów wojskowych na terenach okupowanych. Szyprowski stawia w tej części wiele tez, z którymi można polemizować. Przykładowo na s. 48 napisał, że w projekcie kodeksu SK

Zob. L. Kania, Stużba Sprawiedliwości..., s. 410.

4 W spisie treści występuje z błędem literowym jako „indeks osobobowy” (s. 4). 
przewodniczącym SK był komendant, który jednocześnie zatwierdzał wydany wcześniej wyrok, „w ten sposób w jednym podmiocie skumulowano funkcję orzekania, jak i kontroli wyroku. W praktyce kontrola wydanego orzeczenia byłaby wtedy iluzoryczna bowiem nie wydaje się, aby komendant nie zatwierdzał wydanych przez siebie wyroków”. Na taką konstatację brak jest jednoznacznych dowodów. Ponadto taka kontrola nie musiała być „iluzoryczna”. Nie wiadomo bowiem, jak by się zachował komendant po wydaniu wyroku, a jeszcze przed jego zatwierdzaniem, gdyby wyszły na jaw dowody uniewinniające skazanego. W tamtym czasie starano się rzetelnie zbierać materiał dowodowy, co przy ówczesnych warunkach przepływu informacji nie było łatwym zadaniem. Mogło się też zdarzyć, że w ostatniej fazie (przed zatwierdzeniem wyroku) dotarły zeznania świadków, które odmieniły los skazanego. Z kolei na s. 56 dowiadujemy się, iż kodeks SK z maja 1940 r. posiadał „formę rozkazu” - na jakiej podstawie takie wnioski? Jeżeli tak by było, to ów kodeks SK znalazłby się zapewne w „Dziennikach Rozkazów Naczelnego Wodza” (wraz z jego tajnymi dodatkami), a tam go nie odnajdziemy ${ }^{5}$.

$\mathrm{W}$ rozdziale trzecim (39 stron) opisane zostały organy procesowe odpowiadające za postępowanie przygotowawcze, czyli prokuratora i jednostki kontrwywiadu ZWZ. Autor wnikliwie przedstawia rolę i współpracę obu tych instytucji, eksponując ich zadania $\mathrm{w}$ zakresie prowadzonego dochodzenia. Przeczytawszy tę część z dużym zainteresowaniem uważam, że należałoby ją lepiej dopracować. Po pierwsze, opisywanie instytucji prokuratora (niewojskowego!), cofając się do XIV w. (s. 87-90), nie wnosi nic do tytułowej problematyki podjętej przez Szyprowskiego. Po drugie, sama nazwa rozdziału „organy procesowe w zakresie dochodzenia i sporządzania wyroków" nie oddaje tego, co możemy znaleźć w jego treści. Nie jest on precyzyjny. Przecież już sam Autor na s. 97 podaje, iż jednostki kontrwywiadu działające w ramach zadań SK odpowiadały za: „wykonywanie akcji likwidacyjnych na podstawie przekazanych wyroków” oraz „informowanie sądu [kapturowego - G.K.] o wykonaniu, bądź niemożności wykonania wyroku”. Co ciekawe, od s. 106 do s. 122 czytelnik odnajdzie wiadomości o organizowaniu grup likwidacyjnych, dostarczaniu im broni, poszukiwaniu dogodnego miejsca na przeprowadzenie egzekucji itd. A więc $\mathrm{w}$ rozdziale oprócz zagadnień związanych $\mathrm{z}$ dochodzeniem i sporządzaniem wyroków (jak jest to ujęte w tytule rozdziału) odnajdujemy również cenne informacje o wykonywaniu wyroków ${ }^{6}$.

\footnotetext{
5 Znajdują się w nich rozkazy w zakresie sądownictwa wojskowego, np. rozkaz Ministra Spraw Wojskowych gen. W. Sikorskiego z 12 XII 1939 r. o wprowadzeniu w życie instrukcji organizacyjnej sądownictwa wojskowego czy rozkaz Naczelnego Wodza z 6 III 1940 r. o utworzeniu sądów polowych i nadanie uprawnień zwierzchnika sądowo-karnego.

6 Ta niefortunna (niepełna) nazwa rozdziału III jest jeszcze bardziej zaskakująca, gdyż Autor we Wstępie napisał, że w nim „przybliża [...] wykonywanie zapadłych przed sądem wyroków” (s. 13).
} 
Ostatnia część książki to swoiste ukoronowanie wszystkich wcześniejszych rozdziałów. Autor na podstawie zachowanych materiałów odtwarza przebieg pięciu spraw, które toczyły się przed SK. Robi to bardzo skrupulatnie, podając najważniejsze fakty wraz z nazwiskami. Zdarza się, jak w przypadku sprawy Edwarda Goli vel Andrzeja Azurewicza i Edwarda Metzgera, iż Szyprowski wykracza poza ramy czasowe określone w tytule książki. Jak już wcześniej wspomniałem, trudno się jednak temu dziwić, skoro dochodzenie to rozpoczęto przed SK, a wyrok wydał Wojskowy Sąd Specjalny.

Całość monografii zwieńczona jest 18 załącznikami (25 stron), 2 schematami procedur przed SK (2 strony), wykazem kryptonimów (2 strony) i ilustracjami (73 strony). Niektóre z tych dokumentów są niezwykle cenne i mogą stać się przyczynkiem do dalszych badań nad wojskowym sądownictwem, np. regulamin prokuratury dla spraw SK i Wojskowego Sądu Specjalnego.

Z obowiązku recenzenta zmuszony jestem podać kilka mankamentów książki Bartłomieja Szyprowskiego, które - w moim odczuciu - wręcz psują w pewien sposób jej wartość.

Po pierwsze, stylistyki w niektórych rozdziałach nie poddano korekcie. Autor nagminnie stosuje wyraz „powyższe”, co zaburza płynne czytanie. Na s. 18 słowo to można spotkać czterokrotnie, na s. 34 dwukrotnie. Przecież istniała możliwość zastąpienia tego słowa innym lub przekształcenia zdania tak, aby tych powtórek uniknąć. Ponadto w pracy sporadycznie spotyka się język publicystyczny, który w naukowej monografii (a za taką uchodzi recenzowana książka) nie powinien występować. Przykładem tego mogą być następujące zdania/zwroty: „ZSRR [...] nie będzie interweniować w sprawie Polski, której całym sercem nienawidzi” (s. 17); „Powyższa decyzja Stalina została przyjęta przez Hitlera histerycznym wybuchem radości” (s. 18); „Kolejną kwestią gmatwającą stosunki” (s. 152).

Po drugie, brak jest stosowania jednolitej pisowni powtarzających się instytucji, dokumentów czy nazwisk. I tak kodeks SK zapisywany był w kilku wersjach: „kodeks Sądów Kapturowych” (s. 80); „kodeks SK” (s. 80 - ta sama strona!!!); „kodeks sądów kapturowych” (s. 87); „kodeks Sądów Kapturowych ZWZ” (s. 90) ${ }^{7}$. Na s. 133 Autor pisze o "Sądzie Kapturowym przy Komendancie Okupacji” (s. 133), by siedem stron później podać zmienioną jego nazwę „przy Dowódcy Okupacji”. Problem ten dotyka pisowni nazwisk w niektórych przypadkach - „Kordecki (Marcyniuk)” (s. 157); „Kordecki-Marcyniuk” (s. 166); „Kordecki” (s. 158); „Marcyniuk” (s. 158); „Marcyniuk" (w cudzysłowie - s. 157). Zresztą pisownia pseudonimów raz opatrzona jest cudzysłowem, innym razem już nie ${ }^{8}$.

\footnotetext{
W tekście widnieje jeszcze wersja „Statut SK” (s. 234), ale w tym przypadku chodzi chyba o Statut Wojskowych Sądów Specjalnych.

8 W większości książki pseudonimy pisane są w cudzysłowie, ale nie wiadomo, dlaczego Autor odstępuje od tego w niektórych fragmentach (np. na s. 232 i 237).
} 
Po trzecie, w treści monografii można natrafić na powtórzenia całych zdań lub pewnych informacji. Przykładowo o „przepiciu pieniędzy” przez „Andrzeja” dowiemy się dwukrotnie na tej samej stronie (s. 226). Z kolei o tym, że „powyższe czyny stanowią zbrodnię zdrady idei pracy niepodległościowej i godzą bezpośrednio w organizację [ZWZ - G.K.] przez narażenie jej opinii wśród społeczeństwa oraz podrywanie do niej zaufania w społeczeństwie, a przez to zaprzepaszczają wysiłki organizacji do odbudowy Państwa" przeczytamy (po niewielkiej ingerencji w składnię) na dwóch kolejnych stronach (s. 233 i 234).

Po czwarte, w monografii pojawiają się błędy merytoryczne ${ }^{9}$, gramatyczne („wykupywać” - s. 147) i leksykalne. Te ostatnie są czasami zdumiewające, gdyż dotyczą słownictwa prawniczego, czyli nieobcego Autorowi z racji jego wykształcenia i profesji. Przede wszystkim po wielekroć błędnie stosuje słowo „zapis"10 jako synonim: przepisu (s. 74, 80-82, 144), informacji (s. 133, 165, 239), normy prawnej (s. 70, 235), znamiona przestępstwa (s. 56), zgody na wykonanie wyroku (s. 218), treści np. paktu czy raportu (s. 19-20 i s. 163 przypis 579), donosu (s. 171, 217, 222) $)^{11}$, protokołu (s. 235). Zagadką jednak wciąż pozostanie sformułowanie „zapisy wyroku w sprawie...”? (s. 144). Być może chodzi o treść, a może protokół czy najzwyczajniej o wyrok.

Innym razem Autor osobę skazaną określa jako „podsądny” (s. 119). A przecież ten ostatni w terminologii prawniczej utożsamiany jest $\mathrm{z}$ podejrzanym czy aresztantem ${ }^{12}$.

Po piąte, Szyprowski we Wstępie napisał, że starał się „korzystać w toku pracy nad niniejszą publikacją [z artykułów, książek itp. - G.K.] i są one wskazane w bibliografii” (s. 10). Tymczasem Autor nie „korzystał”, a „przepisywał” całymi fragmentami swoje wcześniej wydane publikacje. Nie widzę przeszkód, aby korzystać (nie przepisywać!) z własnej twórczości, o ile ma to charakter minimalny i oznaczone jest to odpowiednio w przypisach ${ }^{13}$. Inaczej praca nabiera cech autoplagiatu, $\mathrm{z}$ czym moim zdaniem mamy do czynienia $\mathrm{w}$ przypadku recenzowanej książki. I tak podam tylko dla przykładu:

- s. 35, 41 to s. 7-8 artykułu Prokurator w sadownictwie Państwa Podziemnego opublikowanym w „Wojskowym Przeglądzie Prawniczym” [dalej: WPP] 2012, nr 1-2;

\footnotetext{
9 W czerwcu 1941 r. nie wybuchła „wojna rosyjsko-niemiecka” (s. 237), lecz „radziecko-niemiecka”.

10 Termin „zapis” (zwykły, windykacyjny) występuje tylko w prawie spadkowym - zob. L. Kaltenbek-Skarbek, W. Żurek, Prawo spadkowe, Warszawa 2011, s. 54-58; P. Księżak, Zapis windykacyjny, Warszawa 2012, s. 36-38; idem, Prawo spadkowe, s. 268-278.

11 W tym jednak przypadku Autor prawdopodobnie zasugerował się terminologią wojennej okupacji - zob. załącznik s. 386.

12 Takiego błędu nie popełniono na s. 125-126.

13 Autor ani razu nie zaznaczył w przypisach, jakoby cytował swoje artykuły.
} 
- s. $80-81$ to s. $11-12-$ j.w.;

- s. 91-92 to s. 17-19 - j.w.;

- s. 75-76 to przypis nr $34-$ j.w.;

- s. 78 to przypis nr 36 - j.w.;

- s. $134-140$ - to s. 3-8 ${ }^{14}$ (z kosmetycznymi zmianami) artykułu Antoni Opecchowski przed sądem podziemnym, WPP 2013, nr 1;

- s. $144-145$ to s. $11-13$ - j.w.;

- s. $156-170$ to s. $52-67^{15}$ artykułu Tragiczna misja kuriera ZWZ Włodzimierza Marcyniuka, WPP 2013, nr 3;

- s. 170-192 to w niewielkiej formie zmieniony cały prawie 22 stronicowy artykuł Sprawa karna ppłk Emila Macielińskiego przed Sądem Kapturowym KG ZWZ (cz. 1), WPP 2013, nr $4^{16}$;

- s. 192-210 to cały 20-stronicowy artykuł Sprawa karna ppłk Emila Macielińskiego przed Sądem Kapturowym KG ZWZ (cz. 2), WPP 2014, nr $1^{17}$.

Oznacza to, że ponad 80 stron książki z 238 (ze wstępem i podsumowaniem, ale bez załączników, ilustracji itp.) to prawie 1/3 materiałów wcześniej opublikowanych przez Autora! Należało więc o tym wspomnieć we Wstępie, jak czynią to niektórzy historycy, którzy w monografii zamieszczają własne artykuły ${ }^{18}$.

Książka Szyprowskiego Sąd Kapturowy przy Komendzie Głównej Związku Walki Zbrojnej w Warszawie (sierpień 1940 r. - listopad 1941 r.). Podziemie w walce ze zdrajcami Rzeczypospolitej, którą czytelnicy uznali w 2016 r. za książkę historyczną roku, jest pozycją interesującą i godną polecenia wszystkim miłośnikom historii. Mam nadzieję, że w przyszłości Szyprowski podejmie trud i postara się napisać kolejną monografię (np. o Wojskowych Sądach Specjalnych), która nie będzie zawierała żadnych uchybień warsztatowych historyka i „przejdzie” rzetelną korektę redakcyjną.

Grzegorz Kulka

14 Tutaj podaję strony z publikacji on-line-https://pk.gov.pl/wp-content/uploads/2016/07/ fe7fa9ae723f2e2aee003cf32a948577.pdf (dostęp 3 V 2018).

15 Interesujące jest, że w książce zastąpiono nazwisko Janusza Wernera danymi Alfreda Klauzala - czyżby doszło do nowych ustaleń? - zob. s. 161 i 163 recenzowanej książki ze s. 57 i 59 artykułu B. Szyprowskiego, Tragiczna misja...

16 Zob. wersję on-line artykułu - https://pk.gov.pl/wp-content/uploads/2016/07/b687ea27fcla1aa12f5883181be197be.pdf (dostęp 3 V 2018).

17 Zob. wersję on-line artykułu: https://pk.gov.pl/wp-content/uploads/2016/07/0cd1d309c4a4e11a0293832b4d37529c.pdf (dostęp 3 V 2018).

18 Zob. K. Tarka, Emigranci na celowniku. Władze Polski Ludowej wobec wychodźstwa, Łomianki 2012, s. 15; idem, Mackiewicz i inni. Wywiad PRL wobec emigrantów, Łomianki 2007, s. 6; P. Ziętara, Anders, Korboński, Sieniewicz... Szkice z dziejów Drugiej Wielkiej Emigracji, Łomianki 2016, s. 6-9. 